\title{
WORK-LIFE EVENTS THEORY: MAKING SENSE OF SHOCK EVENTS IN DUAL-EARNER COUPLES
}

\author{
WAYNE S. CRAWFORD \\ University of Texas at Arlington \\ MERIDETH J. THOMPSON \\ Utah State University \\ BLAKE E. ASHFORTH \\ Arizona State University
}

\begin{abstract}
Dual-earner couples are increasingly prevalent and encounter demands arising from each partner's commitment to various work and life domains. Unfortunately, there has been little theoretical progress in explaining how dual-earner couples navigate worklife shock events, which we define as disruptive, novel, and critical events that require investment of $\alpha$ couple's resources. Drawing from identity and sensemaking theories, we develop $\alpha$ theory of work-life shock events to explain how dual-earner couples perceive and respond to these events. We theorize that partners initially make sense of the event as individuals and then engage in couple-level sensemaking. We argue that each individual's shock intensity perceptions are shaped by the shock event's characteristics and the identity factors of role salience hierarchy and future self. A subsequent couplelevel process of sensemaking ensues, influenced by the salience of the originating domain and partner role, as well as relational identity factors. Couple-level shock intensity perceptions result in the couple's decision regarding resource investment in the shock event's originating domain. We discuss implications for future research and for organizations.
\end{abstract}

Want to hear a sick joke? A husband and wife walk into the emergency room in the late evening on Sept. 5, 2015. A few hours and tests later, the doctor clarifies that the unusual pain the wife is feeling on her right side isn't the no-biggie appendicitis they suspected but rather ovarian cancer (Rosenthal, 2017).

The above quote from book author, filmmaker, and radio show host Amy Krouse Rosenthal poignantly illustrates the disruptive nature of a worklife shock event. In Ms. Rosenthal's case the shock event was a diagnosis of ovarian cancer. For others it may be news of a layoff, an unexpected opportunity to be promoted at work, or an unplanned pregnancy. While many can identify with the experience of trying to make sense of and respond to such events, scholars have given little theoretical attention to how an individual and the couple as a whole may engage in this process.

The first two authors contributed equally to this article. We would like to thank guest editor Tammy Allen and three anonymous reviewers for their efforts in the development of this paper. We would also like to thank Bruce Barry, Steve Elias, Ingrid Fulmer, Jenny Hoobler, and Randy Settoon for their extremely useful comments on earlier versions of the manuscript.
Integrating work and life has been a prominent focus of both management scholars and practitioners for the last two decades. That issues involving work and life are significant and frequently studied is evidenced by multiple work-life metaanalyses in recent years (e.g., Allen, French, Dumani, \& Shockley, 2015; Allen et al., 2012; Butts, Casper, \& Yang, 2013). An increasingly popular trend is both partners in a relationship working outside the home. In Canada and the United Kingdom, dual-earner couples account for the majority of couples with dependent children (Morshall, 2009; Plunkett, 2012). Further, as millennials continue to enter the workforce, such arrangements will become even more prevalent. In fact, Ernst \& Young's (2015) Global Generations report, based on thousands of employed millennials, showed that approximately 75 percent report being in a couple where both partners work full time. We focus the present research on dual-earner couples, in which both partners participate in the paid labor force. In addition, in such couples, demands placed on the partners require some degree of coordination between work and life roles both at the partner and couple levels (Rachlin, 1987). 
In balancing two jobs and their nonwork lives, dual-earner couples may encounter idiosyncratic complexities when unexpected and jarring events occur. We define a work-life shock event as a disruptive, novel, and critical event (Morgeson, Mitchell, \& Liu, 2015) necessitating that additional resources be invested in the domain the shock originated from. Examples of work-life shock events include, but are not limited to, being offered a promotion that requires additional work hours or relocation, discovery of an unplanned pregnancy, a significant other's diagnosis of a life-threatening illness (per the opening quote), and loss of one's home in a flood or fire. Thus far the field of management has offered little with respect to how couples manage the dynamic nature of their worklife resource investments and, more specifically, how they make sense of and respond to shock events that may disrupt the status quo of those investments (one exception is the specific shock of the decision to relocate [Challiol \& Mignonac, 2005; Eby et al., 2002], wherein prior research suggests that the decision is a function of occupational and family roles within the dual-earner couple [Challiol \& Mignonac, 2005]).

We introduce a theory of how dual-earner couples make sense of and respond to work-life shock events. We integrate identity (Stryker, 1980) and sensemaking (Weick, 1995) theories to propose that each partner's role identities shape these responses. Specifically, we contend that a worklife shock event activates an evaluative sensemaking process that influences how both partners in a dual-earner couple perceive the event and how they choose to invest their resources, such as time, attention, and effort, across the various work and life domains.

We contribute to the work-life literature in three ways. First, we extend prior theory on dual-earner couples by taking a dyadic approach and integrating identity and sensemaking theories to explain how these couples make sense of and respond to a shock from one partner's work or life domain, or a shock that arises for both partners (e.g., a death in the family). Thus, our theory incorporates the complexity and interdependencies inherent in dual-earner couples, allowing us to achieve a more comprehensive picture of each partner's sensemaking, as well as the couple's joint sensemaking.

Second, we fill the gap related to how a work-life shock event affects dual-earner couples by theorizing that the couple's response to the event is influenced by partner- and couple-level sensemaking. Specifically, each partner's sensemaking of the work-life shock event shapes couple-level sensemaking and therefore influences the subsequent level of resource investment toward the domain the event originated from.

Finally, we move beyond the two-domain (i.e., work and family) approach to studying dualearner couples by developing a theory that includes all the work and life domains each partner may participate in and that may impact these couples. To focus only on the work and family roles is to ignore other roles an individual derives meaning and identity from (e.g., Brott, 2005; Crooker, Smith, \& Tabak, 2002; Keeney, Boyd, Sinha, Westring, \& Ryan, 2013), which results in an incomplete picture of how the portners interpret and respond to a work-life shock event. Thus, we seek to extend our understanding of dual-earner couples by providing a holistic view of the work and life roles partners engage in and how those roles may affect both the perceptions of a shock event and the couple's response to it.

In the ensuing sections we propose a dynamic theory of sensemaking in dual-earner couples. The article is structured in four major sections. First, we review the literature on dual-earner couples, highlighting the unique demands faced by such couples, as well as shortcomings in the literature. Second, we define work-life shock events and discuss how they affect resource investments of dual-earner couples. Third, we present our theory of sensemaking in dual-earner couples. We propose an explanation of how partners in dual-earner couples develop shock intensity perceptions as individuals, which then leads to a process of sensemaking for the couple. We further discuss how dual-earner couples make decisions about resource investment in response to shock events, and we present individual identity and relational identity factors that affect the sensemaking process for such couples. Fourth, we conclude with a discussion of the implications of our theory for work-life researchers and organizational practitioners.

\section{DUAL-EARNER COUPLES}

Dual-earner couples face unique challenges in balancing the simultaneous demands of two jobs with fomily relationships (Gupta \& Jenkins, 1985), other relationships, and related demands in the work and life domains. Early findings on the 
work-life experiences of these couples indicated that work-family conflict negatively influences the quality of an individual's work and family lives (Greenhaus, Parasuraman, Granrose, Rabinowitz, \& Beutell, 1989; Higgins, Duxbury, \& Irving, 1992) and that men in dual-earner marriages experience more negative work-family spillover than men not in dual-earner marriages (Higgins \& Duxbury, 1992; Parasuraman, Greenhaus, Rabinowitz, Bedeion, \& Mossholder, 1989). In more recent research, scholars have investigated how work and family experiences cross over from one domain to the other among partners in a dual-earner relationship (Bakker, Demerouti, \& Burke, 2009; Bakker, Demerouti, \& Schaufeli, 2005; Hammer, Allen, \& Grigsby, 1997; Wayne, Casper, Matthews, \& Allen, 2013; Westman, 2001), highlighting the reality that a couple's work and life domains are inextricably interdependent. For instance, one partner's job demands can cross over to impact the home demands of the other partner and can heighten exhaustion in both partners (Bakker, Demerouti, \& Dollard, 2008). Similarly, mood has also been found to cross over between partners in a dual-earner relationship (Song, Foo, \& Uy, 2008).

Dual-earner couples are unique in that partners must consider each other's career demands as they decide how to prioritize the two careers (Livingston, 2014). On the one hand, partners in a dual-earner arrangement find themselves having to lean in (or out) of work and life domains contingent on the other partner's role demands. Dual-earner couples also face unique constraints on time and other resources when making decisions regarding how to best manage the competing demands of work and nonwork domains (Byron, 2005). On the other hand, partners in a dual-earner couple may provide one another with an enhanced ability to balance work with nonwork responsibilities or activities such as engaging in leisure pursuits (Premeaux, Adkins, \& Mossholder, 2007). For example, one partner's work situation may offer resources that allow the other partner to pursue endeavors in their life or work domains, such as going back to school (education domain) or job searching after a layoff (Rusconi, Moen, \& Kaduk, 2013). Closely mirroring scholarly thought, practitioner-oriented articles on dualearner couples focus on navigating trade-offs, balancing career and marriage, and staying married to your partner and job (Ceniza-Levine, 2016; Green, 2016; Valcour, 2015).

Unfortunately, existing research on dual-earner couples has several shortcomings. First, it takes a largely static view of couples' work-life experiences. Much of the early dual-earner couple literature focuses on relationships between specific variables unique to each partner and emphasizes unidirectional effects (e.g., Portner A's work experience impacting Portner B's home experience; Matthews, Del Priore, Acitelli, \& Barnes-Forrell, 2006; Pines, Neal, Hammer, \& Icekson, 2011). However, given that dual-earner couples are under constant pressure to make changes in resource allocations because of the dynamic nature of the work-life interface and the competing demands that originate in each of those domains (Hammer et al., 1997), a dynamic approach is needed.

Second, theory on dual-earner couples must take a broader and yet also specific view by recognizing that there are three entities involved in the social system of such couples: Partner A, Partner B, and the couple as a whole. Thus, we seek to answer the call by Greenhaus and Powell (2012) for theory building related to decision making at the couple level of analysis and to understand the conditions under which one partner's domain-specific decisions may be influenced by the other partner. In doing so we seek to change the conversation about how we study the mutual impact of work and life domains and, more specifically, how we study dual-earner couples.

Third, research on dual-earner couples is often constrained to only the work and fomily domains. Despite calls to examine (a) the work-family nexus in its entirety (Lambert, 1990), (b) the importance of broadening the scope to work and life rather than just work and family (Crooker et al., 2002), and (c) the intersection of the work and life domains of both partners in a dual-earner relationship (Voydanoff, 1988), the life domain has largely been ignored. Further, the life domain has multiple subdomains (Keeney et al., 2013), including family, that individuals can identify with. We develop a theory of dual-earner couples' sensemaking of and responses to shock events such that our framework can be applied to either the work or life domain. Our theory acknowledges and lends itself to the incorporation of all the domain-specific roles a partner may engage in. Furthermore, in dual-earner couples a work-life shock event has the potential to impact at least one valued identity for each partner, and because identities strongly affect sensemaking, and vice versa (Weick, 1995; Weick, Sutcliffe, \& Obstfeld, 2005), it is important to broaden the scope of theorizing to work-life domains. 
Fourth, positioning work and life as static attitudes and perceptions held by dual-earner partners misses the dynamism of experiences in these domains (cf. Ramarajan \& Reid, 2013). Moreover, taking a static approach overlooks the reality of decision making within dual-earner couples responding to shock events, as well as the inherent dynamism of any implicated individual and relational identities. Thus, our theory more effectively accounts for the unfolding nature of evaluations of and responses to work-life shock events in these couples.

Finally, we believe the compelling need for this model lies in the unique interdependence that exists within a couple where both partners are in the paid labor force. Research focusing on the crossover effects between relationship partners (e.g., Bakker et al., 2008; Song et al., 2008) provides substantial evidence that what happens to or affects one partner also likely affects the other partner. This is not only because their roles as partners are interdependent but also because many of their other roles are interdependent as well (Hommer et al., 1997). Further, this model is important for dual-earner couples in that a work role consumes a significant portion of $\alpha$ partner's time and energy, thus magnifying the implications of a dual-earner couple's interdependency.

\section{WORK-LIFE SHOCK EVENTS}

As noted above, we define a work-life shock event as a disruptive, novel, and critical event that necessitates additional resource investment in the domain the shock originated from. A worklife shock event can be positive, as with an unexpected promotion opportunity that carries with it a significant increase in compensation; negative, as with a family member's diagnosis of a lifethreatening illness; or both, as events are often multifaceted and entail opportunities and threats. The notion of a shock is not new and is often used in turnover research to analyze factors motivating a potential decision to leave one's job (Holtom, Mitchell, Lee, \& Inderrieden, 2005; Lee \& Mitchell, 1994). As noted, we draw on Morgeson and colleagues' (2015) characterization of a shock as having three features: a sense of disruption, novelty or newness, and criticality. We offer and theorize about a fourth characteristic specific to a work-life shock event: the event appears to necessitate an increased investment of the couple's resources toward the shock's originating domain.
Each of the four characteristics may signal the need for the couple to reevaluate the status quo (Zellmer-Bruhn, 2003). Work-life shock events vary in each of the four characteristics. For example, while some shock events may be highly disruptive but only somewhat novel (e.g., repeated transfers requiring relocation for a work role), others may be highly disruptive and highly novel (e.g., a child being diagnosed with autism).

First, an event is disruptive if it undermines the continuity in a given environment (Hoffman \& Ocasio, 2001). When an event is disruptive, the manner in which things have been conducted in the past becomes untenable (Morgeson et al., 2015), fostering reanalysis of the current situation to determine what adjustments need to occur (Stigliani \& Ravasi, 2012; Zellmer-Bruhn, 2003). A shock is necessarily disruptive in that it causes a couple to think about how to respond to the event, as opposed to reflexively responding to it (Gersick \& Hackman, 1990; Morgeson, 2005).

Second, an event is novel to the degree that it differs from past events (Morgeson, 2005). Broadly speaking, a work-life shock event's novelty will present itself in the form of new information, such as a positive pregnancy test when a couple was not trying to conceive, learning that one partner has the opportunity for a significant promotion, or the diagnosis of a life-threatening illness of a family member. When an event is commonplace, there is little or no need for the dual-earner couple to reevaluate their current situation because prior responses and routines can be applied without such evaluation. However, with a novel event there are few or even no rules the couple can rely on when responding to the shock (Withey, Daft, \& Cooper, 1983).

Third, an event is critical when it is "important, essential, or a priority" (Morgeson \& DeRue, 2006: 273). Critical events elicit an individual's attention (Gersick \& Hackman, 1990). Like disruption and novelty, a work-life shock event's criticality triggers the dual-earner couple to evaluate the situation and determine if adjustments are needed. The more critical the work-life shock event, the more likely the couple will take action to address the event's implications.

Fourth, as we discussed above, we further define a work-life shock event as necessitating increased investment of the couple's resources toward the event's originating domain, where the "couple's resources" are a pool composed of the resources of each partner and any resources 
resulting from synergies between the partners. Resource investment is the application of resources such as time, effort, and finances to a particular role domain in order to protect against resource loss, recover from prior losses, or attain additional resources (Hobfoll, 2001). That is, for the event to be a shock, at least one partner must view it as requiring resource investment toward the originating domain. Additionally, while work-life shock events necessitate resource investment, shock events can also provide resources to the couple, such as when a significant salary increase accompanies a promotion.

A work-life shock event, whether positive or negative, triggers a reevaluation and potential change of the status quo in the form of how the dual-earner couple invests their time, effort, finances, and so on, and this evaluative process may be a rational, intentional endeavor or a subconscious and less than rational one (Lee \& Mitchell, 1994). Figure 1 summarizes our arguments. First, at the partner level (i.e., the left side of Figure 1), we propose a sensemaking theory of how work-life shock events lead to individuallevel shock intensity perceptions. We also argue that certain identity factors (role salience hierarchy and future self) affect each partner's own sensemaking process. Second, at the couple level (i.e., the right side of Figure 1), we propose that each partner's shock intensity perceptions shape sensemaking within the couple. We further theorize that certain couple-level relational identity factors (scripts, tension, and dominance) and individual role salience influence how a couple makes sense of a work-life shock event. The couple may find that the event creates expectations in the originating role that make the fulfillment of another role more challenging, or even that the fulfillment of expectations from multiple domains is mutually exclusive (Greer \& Egan, 2012). Thus, those role expectations create a demand for resources that the couple must make sense of and then determine how to address with respect to their work-life arrangements.

FIGURE 1

\section{Sensemaking of Work-Life Shock Events for Dual-Earner Couples}

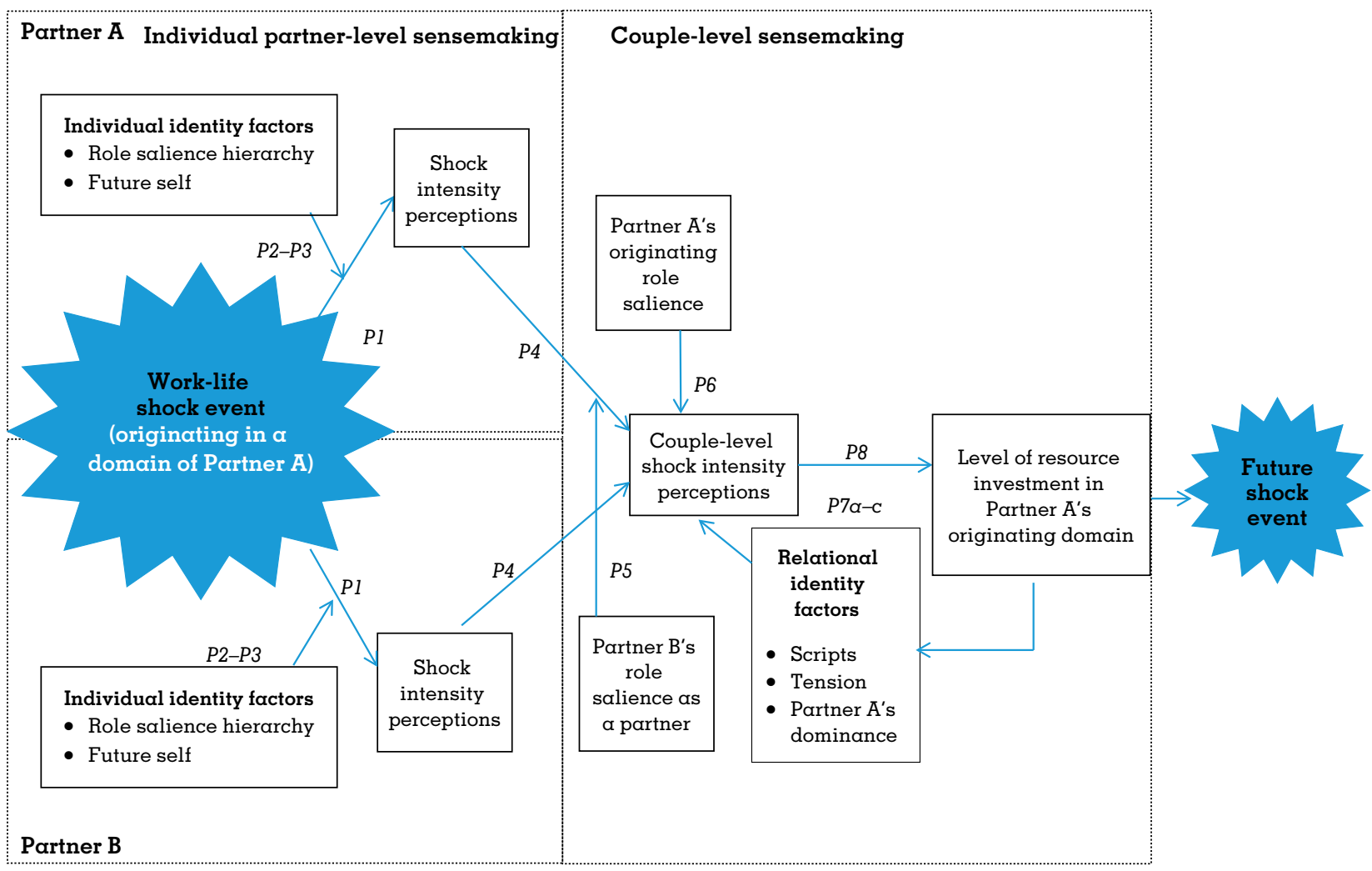




\section{SENSEMAKING AT THE PARTNER LEVEL}

As noted, shock events are disruptive, novel, critical, and resource demanding. As such, they are inherently equivocal and, whether positive or negative, potentially life altering. Thus, we contend that the greater the disruption, novelty, criticality, and resource demands, the more intensely an individual will perceive the shock event and the greater their perceived need to analyze the event will be (e.g., "What happened? Why did it happen? What should I do?"). In short, a shock event triggers a felt need for sensemaking (Maitlis \& Christionson, 2014; Weick, 1995), or turning circumstances "into a situation that is comprehended explicitly in words and that serves as a springboard to action" (Taylor \& Van Every, 2000: 40). Sensemaking may suggest the desirability of a change in resource investments, and the four shock event qualities help the individual construe how urgent and difficult that change may be.

Proposition 1: The shock event's level of disruptiveness, novelty, criticality, and implied resource investment will relate positively to partner-level shock intensity perceptions.

As noted, identity and sensemaking are reciprocally related in that identities often facilitate sensemaking (Weick et al., 2005) and maintaining one's identities in the face of potential threats is " $\alpha$ core preoccupation in sensemaking" (Weick, 1995: 20). Identities are the "meanings that persons attach to the multiple roles they typically play in highly differentiated contemporary societies" (Stryker \& Burke, 2000: 284). These meanings are a function of the perceived social expectations associated with the roles (e.g., managers should develop their subordinates), along with the role incumbent's own idiosyncratic preferences and ways of fulfilling the expectations (e.g., I will give my subordinates stretch assignments; Ashforth, 2001; Sluss, van Dick, \& Thompson, 2010). By internalizing the meanings attached to roles, an individual gains a sense of "who I am" in relevant social contexts, along with a sense of purpose and connection. As role-related personas, identities provide a normative framework for not only sensemaking but also behavior, decision making, and self-evaluation (e.g., Ashforth, 2001; Hoelter, 1983; Thoits, 1983; Weick, 1995). Identities, in short, strongly influence how one engages with the local context.
An example is gender identity. Research suggests that, compared to men, women tend to prioritize and place greater importance on roles in the family, friend, and romantic relationship domains (Blais, Vallerand, Brière, Gagnon, \& Pelletier, 1990; Thoits, 1992). Additionally, masculine gender self-schemas emphasize the career role, whereas feminine gender self-schemas emphasize the family role (Eddleston, Veiga, \& Powell, 2006) or roles viewed as feminine or communal (i.e., friendships, romantic relationships, family; Powell \& Greenhaus, 2010).

Individuals, of course, typically occupy multiple roles and therefore have multiple identities, such as employee, romantic partner, parent, friend, traveler, athlete, and volunteer (Ramarajon, 2014; Thoits, 1992). Thus, a single work-life shock event may potentially destabilize more than one identity. Fundamental to theories of work and life is the idea that time, energy, and finances are not unlimited resources and, thus, if more resources are going to one identity, then necessarily fewer are going to others (Edwards \& Rothbard, 2000), and an individual must choose which will get the lion's share of resources in response to a shock event. This begs the important question of how the multiplicity of identities may affect the sense that one makes of a given shock event and, thus, how one responds. We propose that two identity factors in particular moderate the relationship between a work-life shock event and the perceived intensity of that event: the partner's role salience hierarchy and the partner's future self.

\section{Role Salience Hierarchy}

As viewed in identity theory (for a review see Burke \& Stets, 2009), individuals implicitly arrange their multiple roles (and associated identities) into a salience hierarchy-salience being "the probability that a given identity will be invoked in social interaction" (Brenner, Serpe, \& Stryker, 2014: 232). Identities that are high in the salience hierarchy are likely to be seen by an individual as both situationally relevant and subjectively important (Ashforth, 200l; McCall \& Simmons, 1978; however, many identity theorists, such as Stryker [1980], emphasize subjective importance). The more salient the role, the more likely the role identity's normative framework will be used to make sense of life events (Vignoles, Regalia, Manzi, Colledge, \& Scabini, 2006; see also Lobel, 1991), shaping an individual's 
perceptions, decisions, and behaviors (Stryker, 1968).

The role salience hierarchy is therefore pivotal in sensemaking when multiple identities are invoked concurrently (Greer \& Egan, 2012; Stryker, 1968)-a frequent occurrence in work-life shock events. Further, positive self-evaluation or esteem hinges on socially validating salient role identities such that individuals look for opportunities to enact and reinforce those identities (Callero, 1985). For instance, an engineer may be offered a threeyear expatriate assignment to help construct dams in a war-torn country. This shock most likely will invoke her work identity but may also invoke her identity as the leader of a local civic organization, since she may be concerned about her ability to fulfill current responsibilities to that organization while abroad. Thus, her identities as an engineer and a volunteer are invoked.

Because individuals tend to invest in roles that are both situationally relevant and subjectively important, when two or more identities are invoked following a work-life shock event, the role salience hierarchy is critical in predicting how on individual will perceive and respond to that event. Thus, when the originating domain of the shock is highly salient to a partner, the characteristics of the event will have a stronger effect on the partner's perceptions of the shock event's intensity.

\section{Proposition 2: A partner's role salience hierarchy will moderate the relation- ship between the work-life shock event and partner-level shock intensity per- ceptions such that the higher the asso- ciated roles in a partner's role salience hierarchy, the stronger the relationship between a work-life shock event's characteristics and partner-level shock intensity perceptions.}

\section{Future Self}

Not only are current identities, in the form of $a$ role salience hierarchy, crucial moderators of the impact of work-life shock events, but the threat and/or opportunity that $\alpha$ shock event presents to an individual's future self or selves must be considered as well. A future self is a cognitive representation of the person the individual hopes and aspires to become (Markus \& Nurius, 1986; Oyserman \& James, 201 1; Strauss, Griffin, \& Parker,
2012). Just as a current identity may be highly salient, so, too, may a future self (e.g., a supervisor strongly desires to become a general manager). Further, just as a highly salient current identity provides a normative framework for sensemaking, behavior, decision making, and self-evaluation, so, too, does a salient future self. Moreover, a highly salient future self may serve as a "homing beacon" (Ashforth \& Schinoff, 2016: 115) in the present, motivating developmental steps toward realizing the longer-term self (e.g., Strauss et al., 2012; Taber \& Blankemeyer, 2015; Zhang, Liao, Yan, \& Guo, 2014).

Thus, if a work-life shock event is perceived as relevant (i.e., as a threat and/or opportunity) to the attainment of an individual's future self in a given role identity, the individual will view the event as having more intensity than an event that the individual does not perceive as relevant. For example, if Partner $A$ is given a promotion opportunity that requires Partner $B$ to devote less time and energy to their career and that conflicts with the future self regarding the work role held by Portner B, Partner B's future self will be threatened, and the strain that results is proportional to the perceived level of threat to that identity (Rothausen, Henderson, Arnold, \& Malshe, 2017).

Proposition 3: A threat and/or opportunity regarding a partner's future self moderates the relationship between the work-life shock event and partnerlevel shock intensity perceptions such that the greater the threat/opportunity to the future self, the stronger the relationship between a work-life shock event's characteristics and partnerlevel shock intensity perceptions.

\section{SENSEMAKING AT THE COUPLE LEVEL}

The interdependent nature of dual-earner couples necessarily means that one partner's actions have implications for the couple as a unit (Bird \& Schnurman-Crook, 2005). Dual-earner couples make decisions regarding resource investment in response to shock events after individually perceiving the event's intensity and engaging in couple-level sensemaking. Research on decision making has investigated power within couples (e.g., Beach \& Tesser, 1993), but joint perceptions of the couple are rarely considered. However, understanding couple-level decisions in response 
to shock events inevitably requires considering joint, couple-level sensemaking of those events.

Sensemaking theory suggests that when a high level of interdependence between two individuals exists, a collective mind can develop (Weick \& Roberts, 1993). As Weick and Roberts (1993) explained, a collective mind develops through interactions within a social system, where individuals view their actions in light of the impact those actions have on the group as a whole (see also Bartley, Blanton, \& Gilliard, 2005; Kozlowski \& Klein, 2000; Rentsch, 1990; Rogers \& Amato, 2000; Smith \& Moen, 1998). Analogously, in a dual-earner couple scenario, partners consider the effects of events and potential courses of action on their family (Greenhaus \& Powell, 2012; Peyton, Pitts, \& Kamery, 2003). For instance, Smith and Moen (1998) found that spouses influence the other spouse's decision to retire. Thus, as partners interact to determine the intensity of a given shock event, a shared understanding - that is, couple-level shock intensity perceptions-tends to emerge.

Sensemaking, of course, is not always a neat and tidy process (Drazin, Glynn, \& Kazanjian, 1999); rather, it may be characterized by divergent frames, viewpoints, and beliefs (Trice, 1993; Weick, 1995). Some scholars view such divergence as a natural outcropping of complex environments (Starbuck \& Milliken, 1988), and this may be particularly true within dual-earner couples struggling to make sense of, and decide how to respond to, a work-life shock event. As noted, such events often implicate multiple role identities, including those of the significant other, which bring their own expectations, history, and other dynamics occurring within the couple.

We conceptualize couple-level shock intensity perceptions as a configural property composed of shock intensity perceptions at the partner level that are jointly negotiated (cf. Strauss, 1978). Following Kozlowski and Klein (2000), we view configural properties as properties of a unit (i.e., couple) based on individual shored experiences or perceptions, but not necessarily in agreement. Configural properties thus originate at lower levels and manifest at higher levels. Because partners' individual shock intensity perceptions may not be congruent, the partners interact to better understand each other's perspective and priorities. Assuming reasonable goodwill, collective perceptions emerge as the partners mutually construct the situation, incorporating each other's perceptions (Kenny \& Acitelli, 1989). The result is couple-level shock intensity perceptions, which reflect the partners' mutual understanding (Kozlowski, 2012).

Proposition 4: Shock intensity perceptions at the couple level emerge via negotiation from shock intensity perceptions at the partner level.

\section{The Importance of Partner B's Role Salience As a Partner}

Partners tend to be motivated to support each other and reinforce the identities and future selves of each partner, as well as their relationship (Jorgenson, 2016; Wood, 1986). Focusing on Partner A, it is thus important to consider how Partner B's role salience as a partner may affect the social construction of couple-level shock intensity perceptions. A couple's limited resources (Edwards \& Rothbard, 2000) make the salience of Partner B's partner role even more critical for understanding how couple-level shock intensity perceptions are negotiated. When Partner B places great importance on their own role as a partner, they will likely support Partner A, thereby reinforcing their own role identity as well as the identity of the couple (Swann, Rentfrow, \& Guinn, 2003). Accordingly, the more salient the partner role for Portner B, the more Portner A's shock intensity perceptions are valued and play a pivotal role in determining shock intensity perceptions held by the couple. In other words, the couple-level shock intensity perceptions are more likely to align with the perceptions held by Portner $A$ in response to a shock event in their originating domain.

Proposition 5: The salience of Partner B's role as a partner moderates the relationship between partner-level shock intensity perceptions and couple-level shock intensity perceptions such that the greater the salience, the stronger the relationship between Partner A's shock intensity perceptions and the couplelevel shock intensity perceptions.

\section{The Importance of Partner A's Role in the Originating Domain}

Considering the multiple domains each partner may identify with, and the superseding nature of salient identities, we propose that the salience of Partner A's role in the originating domain is positively related to how intensely a shock is 
viewed by a couple. As the couple shares perceptions related to the event, the partners are (or become) aware of the relative salience that Portner A associates with their own role in the originating domain. As partners negotiate the intensity of a given shock, each partner considers the other's perceptions (Bartley et al., 2005; Rogers \& Amato, 2000; Smith \& Moen, 1998), which results in more intense shock perceptions at the couple level when Partner A places great importance on the role in the originating domain. For example, if Partner A highly identifies with their role in the work domain (e.g., highly values their job, desires to be promoted), shocks originating in the work domain will more likely result in heightened shock intensity perceptions at the couple level. If Portner A is interested in pursuing new career opportunities, the couple will be more likely to view an opportunity for Partner $A$ to take a promotion that requires relocation as an intense shock since Partner A's role in that domain is salient. The intensity perceptions at the couple level will be less intense if Portner A places little value on the work domain. Thus, we argue that the salience of Partner A's role in the originating domain has a positive relationship with shock intensity perceptions held by the couple.

Proposition 6: The salience of Partner A's role in the originating domain will be positively related to couple-level shock intensity perceptions.

\section{Relational Identity Factors}

We noted previously how the individual identity factors of role salience hierarchy and future self affect the sensemaking of each partner (Propositions 2-3). When partners engage in dyadic sensemaking, relational identity factors become important. Following Sluss and colleagues, relational identity refers to the understanding partners have about their relationship-who "we" are and how we do things (e.g., Sluss \& Ashforth, 2007; Sluss, Ployhart, Cobb, \& Ashforth, 2012). ${ }^{1}$ Relational identities reflect the complementary

\footnotetext{
${ }^{1}$ Relational identity has also been described as a traitlike attribute where one is predisposed to define oneself in terms of a relationship ("I am a spouse") rather than as an individual ("I am ambitious") or as a member of a group or collective ("I am a German"; e.g., Acitelli, Rogers, \& Knee, 1999; Brewer \& Gardner, 1996). In contrast, per Sluss and colleagues' definition, every relationship has an associated relational identity, just as every role has an associated role identity.
}

roles of each partner vis-à-vis the other (e.g., significont other-significont other, primary breadwinnerprimary homemaker) along with their mutual understanding of how these roles are enacted. Because no two couples enact a given set of complementary roles exactly alike, relational identities vary across couples. This is important becouse it suggests that the following set of relational identity factors may significantly shape the couple-level shock intensity perceptions that emerge from each partner's individual perceptions.

Relational scripts. Couple-level sensemaking may be simplified when the couple has scripts that help them decipher a given shock event. Scripts are preexisting plans of action based on past experience, observations of others, negotiation, and social expectations (Fiske \& Taylor, 1991; Lee, Mitchell, Holtom, McDaniel, \& Hill, 1999). We define relational scripts as rules or plans that are created by one or both partners that pertain to the couple. As with scripts generally, relational scripts vary in complexity, from simple decision rules (e.g., "If a promotion involves moving to a new city, consult with our parents") to intricate decision trees that allow for various contingencies. Similarly, they vary from concrete to abstract, explicit to implicit, and situation specific to generic. Because shock events, even positive ones, are intrusive and potentially disruptive of the status quo, they tend to arouse high stress (cf. Hobfoll, 1989; Weiss \& Cropanzano, 1996). Relational scripts tend to reduce this stress by helping a couple perceive on event as more readily comprehensible (e.g., "This is sort of like the time that you had that car accident") and manageable (e.g., "... and we were able to cope with that"). Thus, similar to the process described in the unfolding model of turnover (Lee \& Mitchell, 1994), if a relational script exists in relation to a shock event, the couple-level shock intensity perceptions related to that event will tend to be less severe.

\section{Proposition 7a: Relational scripts will reduce couple-level shock intensity perceptions.}

It should be added that there is an inverse relationship between the novelty of an event and the existence of relational scripts. That is, the more experience a couple has with a given event (e.g., unexpected job transfers), the more likely they are to develop relational scripts.

Relationship tension. Whereas relational scripts may reduce the couple's perceived intensity of 
a work-life shock event, other factors in the partners' lives and relationship may increase perceived shock intensity. One potentially major factor is relationship tension, or the presence of strain between partners and the level of irritation one partner has toward the other partner. Higher levels of relationship tension have been found to negatively impact a couple's satisfaction with the family and marriage and with the partners' ability to function effectively in the family domain (e.g., Matthews et al., 2006). Major components of family functioning are problem solving and decision making (Epstein, Baldwin, \& Bishop, 1983). Thus, high relationship tension may undermine the ability and perhaps willingness of partners to collaborate effectively in making sense of the shock event, exacerbating its intensity. Additionally, the negative emotion associated with tension may further heighten the perceived intensity of the event (cf. Cloven \& Roloff, 1991).

Proposition 7b: Relationship tension will increase couple-level shock intensity perceptions.

Relational dominance. Another factor that may play a key role in couple-level perceptions of a shock's intensity is the degree of Partner A's dominance in the relationship. While family power dynamics change, power in couples has often been equated with the relative resources provided by each partner. Blood and Wolfe's (1960) relative resources theory, built on by Becker's (1981) theory of human capital in fomilies, equates the partner's decision-making power to the relative amount of socioeconomic resources contributed by that partner. Under these models, influence on the couple's sensemaking process and collective mind about the shock event's intensity directly varies with the relative amount of resources provided by a partner and the number of external alternatives for each partner's skills.

However, family power is usually associated with gender, with male partners generally having more power and influence. Men's dominance reflects the socially constructed nature of gender roles, which children and adults are often socialized to accept (Lippa, 2005; Tichenor, 2005). Men and women face expectations that they "should be" the primary provider and homemaker, respectively (Eagly, Wood, \& Diekman, 2000). Further, even when women provide more relative resources, they may not be able to activate their power to the extent their male counterparts con (Becker \& Moen, 1999; Bielby \& Bielby, 1992; Davis \& Greenstein, 2013). The fact that power dynamics and dominance within dual-earner couples are complex phenomena is exemplified by findings that women with higher earning power still tend to do more housework, which is traditionally associated with the homemaker role, than their male partners (Bittman, England, Folbre, Sayer, \& Matheson, 2003). That said, evolving gender roles provide a less clear delineation of family power (Peyton et al., 2003). More women are participating in the workforce, at times providing more financial resources to the couple, and are less tolerant of inequality (Van Willigen \& Drentea, 2001). Indeed, for some decisions, women perceive themselves as exerting more influence than their partners (Bartley et al., 2005).

Regardless of how gender roles continue to evolve, relational dominance in couple sensemaking is not solely a function of gender. Assuming for pedagogical purposes that the shock event originates in one of Partner A's domains, our fundamental argument is that the more relationally dominant Partner $\mathrm{A}$ is, the greater the couple-level shock intensity perceptions will be.

Proposition 7c: Partner A's relational dominance will increase couple-level shock intensity perceptions.

\section{Couple-Level Shock Intensity Perceptions and Resource Investment}

The process of sensemaking at the couple level will ultimately determine whether a couple chooses to invest resources in a shock event. Partners go through the process of sensemaking in a dyadic fashion, considering each partner's thoughts in order to make a decision about resource investment (Balogun \& Johnson, 2005; Smith \& Moen, 1998). A shock that the couple views as more intense is more likely to cause the couple to invest resources, creating a new resource arrangement for the couple. Similar to the idea of event strength (Morgeson et al., 2015), we thus expect that shock event intensity as perceived by the couple will influence the likelihood and extent of resource investment.

Partners must jointly determine the extent to which the couple will invest resources in Partner A's originating domain-and how such an investment will ultimately affect the couple's 
resource arrongement. For example, if Partner A is highly committed to their profession (i.e., the work role is salient), a shock event may be learning of a promotion opportunity for Partner $A$ that they have long sought. However, this shock event may require Partner B (whose work role may also be very salient) to scale back hours in the work domain to assist with obligations within the household management domain (e.g., paying bills, household improvements, cleaning) or the family domain (e.g., caring for a child, parentteacher meetings, driving to and from daycare). Although the couple may conclude that reallocating resources (i.e., Partner $A$ investing more time and energy in the work domain and Partner $B$ investing more time and energy in the household management or family domain) is the best decision for the couple, such resource investment decisions are arrived at following a process of sensemaking at the couple level. Interestingly, the multiple domains in each partner's role salience hierarchy complicate this situation. In this case, since Partner B values the work role, not only might Partner $B$ be required to invest resources in a domain not highly valued (i.e., household management domain) but they might also be required to allocate fewer resources to a domain that holds a loftier position in the hierarchy (i.e., work domain).

As the partners go through the sensemaking process at the couple level, they may share stories (Koenig Kellas, Trees, Schrodt, LeClair-Underberg, \&Willer, 2010); may consider the relative resources provided by each partner (Blood \& Wolfe, 1960), the other partner's perceptions (Bartley et al., 2005; Rogers \& Amato, 2000; Smith \& Moen, 1998), and the relatedness of the decision to other domains (Greenhaus \& Powell, 2012); and may search for compromise solutions (Challiol \& Mignonac, 2005). The interdependence between partners in dualearner couples continues to complicate the process of sensemaking. For example, if Portner A highly identifies as a partner, arrongements that result in Partner B having fewer resources (e.g., time, energy) to devote to developing their relationship, owing to additional demands from a shock event in the work domain, will affect Partner A, regardless of whether Partner $\mathrm{A}$ is required to spend more of their own resources in potentially less salient domains (e.g., maintaining their household). In other words, even if Partner A's resource investments remain unaltered, they will be affected if Partner B is unable to invest resources in the relationship with Partner A, while Partner A's resources are expended further in the work domain. Only through a process of dyadic sensemaking at the couple level can issues of resource investment be resolved. Thus, we propose that partners in dual-earner couples jointly engage in sensemaking to make decisions about resource investment based on couple-level shock intensity perceptions. More specifically, the intensity of the perceptions will influence the level of resources the couple decides to invest in Partner A's originating domain. Shock events command attention and, in doing so, motivate a potential shift in the investment of a couple's resources (Morgeson et al., 2015).

Proposition 8: Couple-level shock intensity perceptions are positively related to resource investment in Portner A's originating domain.

\section{DISCUSSION}

In this article we consider how dual-earner couples make sense of and respond to shock events that impact their work-life resource investments. We provide a theoretically grounded framework and discuss a dyadic sensemaking process that (1) proposes and defines work-life shock events, (2) examines this phenomenon through a lens that views the couple as a unit with two interdependent partners rather than two separate and independent partners, (3) positions two individual identity factors as critical to shoping each partner's own sensemaking of the shock event's intensity, and (4) acknowledges that couple-level relational identity factors, as well as the role salience of Partner A's role in the originating domain and Partner B's role as a partner, influence the couple's sensemaking of the event and, thus, their response to it. Given the potential interplay among the numerous work and life domains between the two partners, we recognize the importance of incorporating partners' experiences, perceptions, and multiple domains into our theory.

We provide several critical contributions that extend the limited theory on dual-earner couples and their work-life resource investments. First, our theory incorporates the complexity and interdependencies that are inherent to dual-earner couples, allowing us to achieve a more complete picture of each partner's sensemaking, as well as the couple's joint sensemaking. While prior 
research recognizes the importance and growing worldwide prevalence of dual-earner couples (Masterson \& Hoobler, 2015), thus for the field of management has offered little with respect to how couples manage the dynamic nature of their worklife resource investments and, more specifically, how they make sense of and respond to shock events that may disrupt the status quo of those investments. By acknowledging the numerous and varied role identities that individuals may value, our theory encompasses the interdependent nature of dual-earner couples and the demands they must juggle in both their work-life roles and their relationship.

Second, our proposed theory acknowledges and lends itself to the incorporation of all the domain-specific roles that partners engage in. Prior research and theoretical developments in the work-life arena have focused almost exclusively on two domains: work and family. Unfortunately, in doing so the field has overlooked the myriad other domains and roles that make up an individual's set of identities and the idea that this set is dynamic. Further, when researchers have explored the intersection of dual-earner couples' work and nonwork domains and roles, their emphasis has been either on the nonwork role of fomily (Aryee \& Luk, 1996; $\mathrm{Nel}$, Koekemoer, \& Nel, 2012) or on nonwork roles in general (Sekaran, 1985). While dual-earner partners are both meaningfully engaged in the work domain, it is likely that they also find meaning and are significantly engaged in specific nonwork domains where shocks may occur (e.g., volunteer, leisure). Our theory highlights the implications of the various roles and competing demands dual-earner couples encounter. In particular, our research can generate new insights about the various roles that individuals derive meaning and identity from and how dualearner couples make decisions that may affect involvement in those roles.

Third, in relation to the many domains dualearner partners may be engaged in, we have discussed various individual and relational identity factors related to these roles that may impact the sensemaking process-both at the partner and couple level-as the partners determine how to respond to a shock event coming from a particular role domain. For instance, some roles may elicit higher commitment from and experienced meaning for an individual, which is often the case with leisure and community involvement, since individuals tend to be more committed to roles in those domains than to the work role (Kelly \& Kelly, 1994). Thus, we extend the sensemaking literature by integrating partners' role salience hierarchy into our theory of a dualearner couple's perceptions of and responses to shock events. While individuals' sense of identity is a central focus of sensemaking theory (Weick, 1995; Weick et al., 2005), the notion that different roles may carry differential significance for an individual (i.e., role salience hierarchy; Stryker \& Burke, 2000) has yet to be incorporated into the sensemaking literature in a meaningful way, particularly when considering dual-earner couples. This is important in that differential significance shapes individuals' experience of and response to a shock event. Further, prior research on role salience among dual-earner couples has focused primarily on career salience and family salience (Bhowon, 2013; Hardesty \& Betz, 1980; Naidoo \& Jano, 2002; Rajadhyaksha \& Bhatnagar, 2000). Given the varied roles individuals in a dualearner couple enact (Blair, 1998; Ugwu, 2009), using a comprehensive approach that incorporates all of those roles and acknowledges that they exist and function in relative importance to one another is critical for achieving a more complete picture of how these couples' work-life arrangements may be shaken and affected by a shock event.

The theory we propose here suggests revisiting how dual-earner couples are studied more generally. Research on dual-earner couples primarily focuses on the impact of one variable from one domain of Partner A on another variable (which could be in a separate domain) for Partner B. Such a siloed approach to both domains and partners hinders the ability of researchers to fully understand the complex process dual-earner couples engage in to make decisions about resource investment. Thus, we suggest that researchers interested in investigating dual-earner couples take a more dynamic and dyadic approach. Specifically, considering attitudes and behaviors of both partners simultaneously is necessary to gain a more comprehensive understanding of the phenomenon.

\section{Extending the Model}

In addition to testing the arguments summarized in Figure 1, future research could explore various promising extensions to the model. 
First, longitudinal study into dual-earner couples offers a very promising area. An investigation of the sensemaking process at the individual and couple levels over time (how these decisions are often made in reality) would provide a valuable contribution. Relatedly, research could shed light on how experience with shock events helps facilitate learning and script development. Further, our theory focuses on the sensemaking of and response to a single shock event in the work-life arrangements of a dualearner couple. However, if one partner's work or life domain-assuming high role saliencekeeps providing more shocks, then, over time, that partner's work or life domain may begin to take precedence in the couple's collective worklife arrangement. At the same time, it may be that the longer shock events originate from a particular partner's specific role domain (e.g., one partner is in the military), the less intense the shocks will be perceived to be, thus becoming less likely to affect the sensemaking process. Finally, a partner's role salience hierarchy most likely changes over time, with different roles occupying higher or lower positions, depending on the individual's career stage and other work and life circumstances (Lobel, 1991), as may occur with the birth of a first child, the last child leaving the nest, the need to care for an aging parent, or one partner reaching retirement age. Indeed, dualearner couples may jointly prioritize one partner's career over the other for a specified time (Challiol \& Mignonac, 2005).

Second, and relatedly, researchers should also explore the extent to which partners experience residual effects of work-life resource investment decisions. Certainly, partners in dual-earner couples recall previous resource investment decisions. Just as employment choices affect, and possibly constrain, both partners and also may have a cumulative effect on each partner (Hertz, 1986), resource investment decisions in response to work-life shock events may carry over to future shock events (as can be seen in Figure 1; Greenhaus \& Powell, 2012). Specifically, when evaluating the intensity of and response to a shock event, previous decisions and tensions in response to related or unrelated shock events may be recalled by each partner and impact the sensemaking process at both the individual and couple level.

Third, the robustness of the theory should be explored by testing it with couples who have children living at home and with those who do not. For instance, couples with children living in the home may experience some shocks more intensely because the shocks are likely to affect the children, as when one partner is diagnosed with a life-threatening illness or a partner gets laid off. Further, the sensemaking process may also be more complicated and onerous for couples with children in that they have critical stakeholders for whom they are responsible. Interestingly, much of the work on formily life cycles (e.g., Allen \& Finkelstein, 2014) positions formilies as experiencing discrete stages across life, and research suggests that career demands parallel formily demands across the life cycle (Moen \& Roehling, 2005). How the process of decision making changes for dualearner couples over time with versus without children warronts investigation.

Fourth, future research should explore the generalizability of our theory beyond dual-earner couples. For example, a partner who is not engaged in a work role is likely engaged in roles related to other domains, such as household management, romantic relationships, leisure, and community involvement. Thus, similar to partners in a dual-earner couple, these roles will still fit into a role salience hierarchy and will influence the partner's sensemaking and also shape the couple's response to a shock event.

Finally, the role of culture has been largely ignored in research specific to work-life issues for dual-earner couples, and future research might examine the applicability of our model across cultural boundaries. The importance of balancing the work and life domains varies widely across countries (Chandra, 2012), and, thus, cultural expectations may play a role in how intense each partner perceives the shock event to be. Further, cultural contexts, whether at the organizational or societal level, may stigmatize the extent to which partners of certain genders should engage in or identify with specific domains (e.g., Ridgeway, 2009). Culture may therefore interact with gender self-schema to impact a partner's perceptions of the intensity of a work-life shock event. Thus, researchers could investigate the extent to which a work-life shock event influences couple-level decision making across different types of organizational and societal cultures.

\section{Implications for Practice}

Our theory of dual-earner couples' sensemaking of and response to shock events has several 
implications for organizations and managers. First, while researchers should take a more holistic approach to studying dual-earner couples and their work-life resource investments, organizations and their managers should also think and act more comprehensively when it comes to dual-earner couples. More than half of employees indicate that the ability to balance work and life is very importont (Society of Human Resource Management, 2016), and organizations should recognize that most new entrants to the workforce are likely part of a dual-earner couple (Ernst \& Young, 2015). Addressing the needs of these couples goes beyond work-life balance in that individuals engage in many roles, and each one stands to help them be more effective workers (Rothbard \& Romarajan, 2009), as may occur with work-to-formily enrichment (Greenhaus \& Powell, 2006), especially when they can perform well in the roles that are highest in the salience hierarchy. Thus, when organizational leaders adopt a more holistic view toward helping dual-earner couples excel in multiple identities, the organization is likely to reap a benefit.

Second, throughout our model-and particularly when a dual-earner couple finds that they must make sense of a shock event and decide if and how resources need to be invested in the immediate future-excellent communication is critical to an effective outcome. Thus, organizations could encourage openness about seemingly extraorganizational life events and help employees build and strengthen their communication and collaborative decision-making skills. This opportunity to enhance a dual-earner couple's skills is important, because interpersonal conflict outside of the workplace often results in low productivity at work (Forthofer, Markman, Cox, Stanley, \& Kessler, 1996).

Third, organizations should recognize the changing nature of decision making for dual-earner couples. As millennials increasingly occupy more of the workforce, a larger number of employees are going to be in dual-earner couples. As proposed in the current research, partners in such couples jointly participate in decision making. Thus, giving consideration to both employees and their partners (and more specifically the roles they consider to be most important) will be crucial for employers to retain top talent.

\section{Conclusion}

The manner in which dual-earner couples respond to a shock event and the subsequent potential impact on resource investments are largely uninvestigated phenomena. We have developed a theory of how couples may consciously or subconsciously evaluate a shock event and then respond to that event. We extend the identity literature and sensemaking literature to describe how decisions made by the couple are shaped by both individual- and couple-level processes. Further, we demonstrate how individual and relational identity factors play a crucial role in how dual-earner couples respond to shock events in their work and life domains.

\section{REFERENCES}

Acitelli, L. K., Rogers, S., \& Knee, C. R. 1999. The role of identity in the link between relationship thinking and relationship satisfaction. Journal of Social and Personal Relationships, 16: 591-618.

Allen, T. D., \& Finkelstein, L. M. 2014. Work-family conflict among members of full-time dual-earner couples: An examination of family life stage, gender, and age. Journal of Occupational Health Psychology, 19: 376-384.

Allen, T. D., French, K. A., Dumani, S., \& Shockley, K. M. 2015. Meta-analysis of work-family conflict mean differences: Does national context matter? Journal of Vocational Behavior, 90: 90-100.

Allen, T. D., Johnson, R. C., Saboe, K. N., Cho, E., Dumani, S., \& Evans, S. 2012. Dispositional variables and work-family conflict: A meta-analysis. Journal of Vocational Behavior, 80: 17-26.

Aryee, S., \& Luk, V. 1996. Balancing two major parts of adult life experience: Work and family identity among dualearner couples. Human Relations, 49: 465-487.

Ashforth, B. E. 2001. Role transitions in organizational life: An identity-based perspective. Mahwah, NJ: Lawrence Erlbaum Associates.

Ashforth, B. E., \& Schinoff, B. S. 2016. Identity under construction: How individuals come to define themselves in organizations. Annual Review of Organizational Psychology and Organizational Behavior, 3: 111-137.

Bakker, A. B., Demerouti, E., \& Burke, R. 2009. Workaholism and relationship quality: A spillover-crossover perspective. Journal of Occupational Health Psychology, 14: 23-33.

Bakker, A. B., Demerouti, E., \& Dollard, M. F. 2008. How job demands affect partners' experience of exhaustion: Integrating work-family conflict and crossover theory. Journal of Applied Psychology, 93: 901-911.

Bakker, A. B., Demerouti, E., \& Schaufeli, W. B. 2005. The crossover of burnout and work engagement among working couples. Human Relations, 58: 661-689. 
Balogun, J., \& Johnson, G. 2005. From intended strategies to unintended outcomes: The impact of change recipient sensemaking. Organization Studies, 26: 1573-1601.

Bartley, S. J., Blanton, P. W., \& Gilliard, J. L. 2005. Husbands and wives in dual-earner marriages: Decision-making, gender role attitudes, division of household labor, and equity. Marriage \& Family Review, 37(4): 69-94.

Beach, S. R. H., \& Tesser, A. 1993. Decision making power and marital satisfaction: A self-evaluation maintenance perspective. Journal of Social and Clinical Psychology, 12: 471-494.

Becker, G. S. 1981. Altruism in the family and selfishness in the market place. Economica, 48: 1-15.

Becker, P. E., \& Moen, P. 1999. Scaling back: Dual-earner couples' work-family strategies. Journal of Marriage and Family, 61: 995-1007.

Bhowon, U. 2013. Role salience, work-family conflict and satisfaction of dual-earner couples. Journal of Business Studies Quarterly, 5(2): 78-90.

Bielby, W. T., \& Bielby, D. D. 1992. I will follow him: Family ties, gender-role beliefs, and reluctance to relocate for a better job. American Journal of Sociology, 97: 1241-1267.

Bird, G. W., \& Schnurman-Crook, A. 2005. Professional identity and coping behaviors in dual-career couples. Family Relations, 54: 145-160.

Bittman, M., England, P., Folbre, N., Sayer, L. C., \& Matheson, G. 2003. When does gender trump money? Bargaining and time in household work. American Journal of Sociology, 109: 186-214.

Blair, S. L. 1998. Work roles, domestic roles and marital quality: Perceptions of fairness among dual-earner couples. Social Justice Research, 11: 313-335.

Blais, M. R., Vallerand, R. J., Brière, N. M., Gagnon, A., \& Pelletier, L. G. 1990. Significance, structure, and gender differences in life domains of college students. Sex Roles, 22: 199-212.

Blood, R. O., \& Wolfe, D. M. 1960. Husbands and wives: The dynamics of married living. Glencoe, IL: Free Press.

Brenner, P. S., Serpe, R. T., \& Stryker, S. 2014. The causal ordering of prominence and salience in identity theory: An empirical examination. Social Psychology Quarterly, 77: 231-252.

Brewer, M. B., \& Gardner, W. 1996. Who is this "we"? Levels of collective identity and self representations. Journal of Personality and Social Psychology, 71: 83-93.

Brott, P. E. 2005. A constructivist look at life roles. Career Development Quarterly, 54: 138-149.

Burke, P. J., \& Stets, J. E. 2009. Identity theory. Oxford: Oxford University Press.

Butts, M. M., Casper, W. J., \& Yang, T. S. 2013. How important are work-family support policies? A meta-analytic investigation of their effects on employee outcomes. Journal of Applied Psychology, 98: 1-25.

Byron, K. 2005. A meta-analytic review of work-family conflict and its antecedents. Journal of Vocational Behavior, 67: 169-198.

Callero, P. L. 1985. Role-identity salience. Social Psychology Quarterly, 48: 203-215.
Ceniza-Levine, C. 2016. Career and marriage: A checklist of questions to help you balance both. Forbes, February 14: http://www.forbes.com/sites/carolinecenizalevine/2016/02/ 14/career-and-marriage-a-checklist-of-questions-to-helpyou-balance-both/\#65589e4a22fb.

Challiol, H., \& Mignonac, K. 2005. Relocation decision-making and couple relationships: A quantitative and qualitative study of dual-earner couples. Journal of Organizational Behavior, 26: 247-274.

Chandra, V. 2012. Work-life balance: Eastern and Western perspectives. International Journal of Human Resource Management, 23: 1040-1056.

Cloven, D. H., \& Roloff, M. E. 1991. Sense-making activities and interpersonal conflict: Communicative cures for the mulling blues. Western Journal of Speech Communication, 55: 134-158.

Crooker, K. J., Smith, F. L., \& Tabak, F. 2002. Creating worklife balance: A model of pluralism across life domains. Human Resource Development Review, 1: 387-419.

Davis, S. N., \& Greenstein, T. N. 2013. Why study housework? Cleaning as a window into power in couples. Journal of Family Theory \& Review, 5: 63-71.

Drazin, R., Glynn, M. A., \& Kazanjian, R. K. 1999. Multilevel theorizing about creativity in organizations: A sensemaking perspective. Academy of Management Review, 24: 286-307.

Eagly, A. H., Wood, W., \& Diekman, A. B. 2000. Social role theory of sex differences and similarities: A current appraisal. In T. Eckes \& H. M. Trautner (Eds.), The developmental social psychology of gender: 123-174. Mahwah, NJ: Lawrence Erlbaum Associates.

Eby, L. T., Douthitt, S. S., Perrin, T., Noble, C. L., Atchley, K. P., \& Ladd, R. T. 2002. Managerial support for dual-career relocation dilemmas. Journal of Vocational Behavior, 60: 354-373.

Eddleston, K. A., Veiga, J. F., \& Powell, G. N. 2006. Explaining sex differences in managerial career satisfier preferences: The role of gender self-schema. Journal of Applied Psychology, 91: 437-445.

Edwards, J. R., \& Rothbard, N. P. 2000. Mechanisms linking work and family: Clarifying the relationship between work and family constructs. Academy of Management Review, 25: 178-199.

Epstein, N. B., Baldwin, L. M., \& Bishop, D. S. 1983. The McMaster family assessment device. Journal of Marital and Family Therapy, 9: 171-180.

Ernst \& Young 2015. Global generations: A global study on work-life challenges across generations. Available at http://www.ey.com/Publication/vwLUAssets/EY-globalgenerations- $\alpha$-global-study-on-work-life-challengesacross-generations/\$FILE/EY-global-generations-a-globalstudy-on-work-life-challenges-across-generations.pdf.

Fiske, S. T., \& Taylor, S. E. 1991. Social cognition (2nd ed.). New York: McGraw-Hill.

Forthofer, M. S., Markman, H. J., Cox, M., Stanley, S., \& Kessler, R. C. 1996. Associations between marital distress and 
work loss in a national sample. Journal of Marriage and Family, 58: 597-605.

Gersick, C. J. G., \& Hackman, J. R. 1990. Habitual routines in task-performing groups. Organizational Behavior and Human Decision Processes, 47: 65-97.

Green, M. 2016. How couples stay married to the job and each other. Financial Times, July 17: https://www.ft.com/content/ c03323ec-49b6-1 le6-8d68-72e921 le86ab.

Greenhaus, J. H., Parasuraman, S., Granrose, C. S., Rabinowitz, S., \& Beutell, N. J. 1989. Sources of work-family conflict among two-career couples. Journal of Vocational Behavior, 34: 133-153.

Greenhaus, J. H., \& Powell, G. N. 2006. When work and family are allies: A theory of work-family enrichment. Academy of Management Review, 31: 72-92.

Greenhaus, J. H., \& Powell, G. N. 2012. The family-relatedness of work decisions: A framework and agenda for theory and research. Journal of Vocational Behavior, 80: 246-255.

Greer, T. W., \& Egan, T. M. 2012. Inspecting the hierarchy of life roles: A systematic review of role salience literature. Human Resource Development Review, 11: 463-499.

Gupta, N., \& Jenkins, G. D. 1985. Dual-career couples: Stress, stressors, strain, and strategies. In T. A. Beehr \& R. S. Bhagat (Eds.), Human stress and cognition in organizations: An integrated perspective: 141-176. New York: Wiley Interscience.

Hammer, L. B., Allen, E., \& Grigsby, T. D. 1997. Work-family conflict in dual-earner couples: Within-individual and crossover effects of work and family. Journal of Vocational Behavior, 50: 185-203.

Hardesty, S. A., \& Betz, N. E. 1980. The relationships of career salience, attitudes toward women, and demographic and family characteristics to marital adjustment in dualcareer couples. Journal of Vocational Behavior, 17: 242-250.

Hertz, R. 1986. More equal than others: Women and men in dual-career marriages. Berkeley: University of California Press.

Higgins, C. A., \& Duxbury, L. E. 1992. Work-family conflict: A comparison of dual-career and traditional-career men. Journal of Organizational Behavior, 13: 389-411.

Higgins, C. A., Duxbury, L. E., \& Irving, R. H. 1992. Work-family conflict in the dual-career family. Organizational Behavior and Human Decision Processes, 51: 51-75.

Hobfoll, S. E. 1989. Conservation of resources: A new attempt at conceptualizing stress. American Psychologist, 44: 513-524.

Hobfoll, S. E. 2001. The influence of culture, community, and the nested-self in the stress process: Advancing conservation of resources theory. Applied Psychology, 50: 337-421.

Hoelter, J. W. 1983. The effects of role evaluation and commitment on identity salience. Social Psychology Quarterly, 46: 140-147.

Hoffman, A. J., \& Ocasio, W. 2001. Not all events are attended equally: Toward a middle-range theory of industry attention to external events. Organization Science, 12: 414-434.

Holtom, B. C., Mitchell, T. R., Lee, T. W., \& Inderrieden, E. J. 2005. Shocks as causes of turnover: What they are and how organizations can manage them. Human Resource Management, 44: 337-352.

Jorgenson, J. 2016. Performing the "two-body problem": An analysis of academic couples' career sensemaking as revealed through joint storytelling. Journal of Family Communication, 16: 403-418.

Keeney, J., Boyd, E. M., Sinha, R., Westring, A. F., \& Ryan, A. M. 2013. From "work-family" to "work-life": Broadening our conceptualization and measurement. Journal of Vocational Behavior, 82: 221-237.

Kelly, J. R., \& Kelly, J. R. 1994. Multiple dimensions of meaning in the domains of work, family, and leisure. Journal of Leisure Research, 26: 250-274.

Kenny, D. A., \& Acitelli, L. K. 1989. The role of the relationship in marital decision making. In D. Brinberg \& J. Jaccard (Eds.), Dyadic decision making: 51-62. New York: Springer.

Koenig Kellas, J., Trees, A. R., Schrodt, P., LeClair-Underberg, C., \& Willer, E. K. 2010. Exploring links between wellbeing and interactional sense-making in married couples' jointly told stories of stress. Journal of Family Communication, 10: 174-193.

Kozlowski, S. W. 2012. Groups and teams in organizations: Studying the multilevel dynamics of emergence. In A. B. Hollingshead \& M. S. Poole (Eds.), Methods for studying small groups: $A$ behind-the-scenes guide: 260-283. New York: Routledge.

Kozlowski, S. W. J., \& Klein, K. J. 2000. A multilevel approach to theory and research in organizations: Contextual, temporal, and emergent processes. In K. J. Klein \& S. W. J. Kozlowski (Eds.), Multilevel theory, research, and methods in organizations: Foundations, extensions, and new directions: 3-90. San Francisco: JosseyBass.

Lambert, S. J. 1990. Processes linking work and family: A critical review and research agenda. Human Relations, 43: 239-257.

Lee, T. W., \& Mitchell, T. R. 1994. An alternative approach: The unfolding model of voluntary employee turnover. Academy of Management Review, 19: 51-89.

Lee, T. W., Mitchell, T. R., Holtom, B. C., McDaniel, L. S., \& Hill J. W. 1999. The unfolding model of voluntary turnover: A replication and extension. Academy of Management Journal, 42: 450-462.

Lippa, R. A. 2005. Gender, nature, and nurture. London: Routledge.

Livingston, B. A. 2014. Bargaining behind the scenes: Spousal negotiation, labor, and work-family burnout. Journal of Management, 40: 949-977.

Lobel, S. A. 1991. Allocation of investment in work and family roles: Alternative theories and implications for research. Academy of Management Review, 16: 507-521. 
Maitlis, S., \& Christianson, M. 2014. Sensemaking in organizations: Taking stock and moving forward. Academy of Management Annals, 8: 57-125.

Markus, H., \& Nurius, P. 1986. Possible selves. American Psychologist, 41: 954-969.

Marshall, K. 2009. The family work week. Perspectives on Labour and Income, 21(2): 21-29.

Masterson, C. R., \& Hoobler, J. M. 2015. Care and career: A family identity-based typology of dual-earner couples. Journal of Organizational Behavior, 36: 75-93.

Matthews, R. A., Del Priore, R. E., Acitelli, L. K., \& BarnesFarrell, J. L. 2006. Work-to-relationship conflict: Crossover effects in dual-earner couples. Journal of Occupational Health Psychology, 11: 228-240.

McCall, G. H., \& Simmons, J. T. 1978. Identities and interaction (revised ed.). New York: Free Press.

Moen, P., \& Roehling, P. 2005. The career mystique: Cracks in the American dream. Lanham, MD: Rowman \& Littlefield.

Morgeson, F. P. 2005. The external leadership of selfmanaging teams: Intervening in the context of novel and disruptive events. Journal of Applied Psychology, 90: 497-508.

Morgeson, F. P., \& DeRue, D. S. 2006. Event criticality, urgency, and duration: Understanding how events disrupt teams and influence team leader intervention. Leadership Quarterly, 17: 271-287.

Morgeson, F. P., Mitchell, T. R., \& Liu, D. 2015. Event system theory: An event-oriented approach to the organizational sciences. Academy of Management Review, 40: 515-537.

Naidoo, A. V., \& Jano, R. 2002. Role salience of dual-career women managers. SA Journal of Industrial Psychology, 28(3): 69-74.

Nel, J., Koekemoer, E., \& Nel, J. A. 2012. Home characteristics, nonwork-work role demands effects on the well-being of dual-earner parents. Journal of Psychology in Africa, 22: 209-220.

Oyserman, D., \& James, L. 2011. Possible identities. In S. J. Schwartz, K. Luyckx, \& V. L. Vignoles (Eds.), Handbook of identity theory and research. Volume 1: Structures and processes: 117-145. New York: Springer.

Parasuraman, S., Greenhaus, J. H., Rabinowitz, S., Bedeian, A. G., \& Mossholder, K. W. 1989. Work and family variables as mediators of the relationship between wives' employment and husbands' well-being. Academy of Management Journal, 32: 185-201.

Peyton, R. M., Pitts, S., \& Kamery, R. H. 2003. A review of significant consumer satisfaction/dissatisfaction models: The family decision-making process. Proceedings of the Academy of Family Business, 1: 3-8.

Pines, A. M., Neal, M. B., Hammer, L. B., \& Icekson, T. 2011. Job burnout and couple burnout in dual-earner couples in the sandwiched generation. Social Psychology Quarterly, 74: 361-386.
Plunkett, J. 2012. Gaining from growth: The final report of the Commission on Living Standards. London: Resolution Foundation.

Powell, G. N., \& Greenhaus, J. H. 2010. Sex, gender, and decisions at the family $\rightarrow$ work interface. Journal of Management, 36: 1011-1039.

Premeaux, S. F., Adkins, C. L., \& Mossholder, K. W. 2007. Balancing work and family: A field study of multidimensional, multi-role work-family conflict. Journal of Organizational Behavior, 28: 705-727.

Rachlin, V. C. 1987. Fair vs. equal role relations in dual-career and dual-earner families: Implications for family interventions. Family Relations, 36: 187-192.

Rajadhyaksha, U., \& Bhatnagar, D. 2000. Life role salience: A study of dual-career couples in the Indian context. Human Relations, 53: 489-511.

Ramarajan, L. 2014. Past, present and future research on multiple identities: Toward an intrapersonal network approach. Academy of Management Annals, 8: 589659.

Ramarajon, L., \& Reid, E. 2013. Shattering the myth of separate worlds: Negotiating nonwork identities at work. Academy of Management Review, 38: 621-644.

Rentsch, J. R. 1990. Climate and culture: Interaction and qualitative differences in organizational meanings. Journal of Applied Psychology, 75: 668-681.

Ridgeway, C. L. 2009. Framed before we know it: How gender shapes social relations. Gender \& Society, 23: $145-160$.

Rogers, S. J., \& Amato, P. R. 2000. Have changes in gender relations affected marital quality? Social Forces, 79: 731-753.

Rosenthal, A. K. 2017. You may want to marry my husband. New York Times, March 3: https://nyti.ms/21GXMFx.

Rothausen, T. J., Henderson, K. E., Arnold, J. K., \& Malshe, A. 2017. Should I stay or should I go? Identity and well-being in sensemaking about retention and turnover. Journal of Management, 43: 2357-2385.

Rothbard, N. P., \& Ramarajan, L. 2009. Checking your identities at the door? Positive relationships between nonwork and work identities. In L. M. Roberts \& J. E. Dutton (Eds.), Exploring positive identities and organizations: Building a theoretical and research foundation: 125-148. New York: Routledge.

Rusconi, A., Moen, P., \& Kaduk, A. 2013. Career priorities and pathways across the (gendered) life course. In D. A. Major \& R. J. Burke (Eds.), Handbook of work-life integration among professionals: Challenges and opportunities: 95-119. Northampton, MA: Edward Elgar.

Sekaran, U. 1985. The paths to mental health: An exploratory study of husbands and wives in dual-career families. Journal of Occupational Psychology, 58: 129137.

Sluss, D. M., \& Ashforth, B. E. 2007. Relational identity and identification: Defining ourselves through work relationships. Academy of Management Review, 32: 9-32. 
Sluss, D. M., Ployhart, R. E., Cobb, M. G., \& Ashforth, B. E. 2012. Generalizing newcomers' relational and organizational identifications: Processes and prototypicality. Academy of Management Journal, 55: 949-975.

Sluss, D. M., van Dick, R., \& Thompson, B. S. 2010. Role theory in organizations: A relational perspective. In S. Zedeck (Ed.), APA handbook of industrial and organizational psychology. Volume 1: Building and helping the organization: 505-534. Washington, DC: American Psychological Association.

Smith, D. B., \& Moen, P. 1998. Spousal influence on retirement: His, her, and their perceptions. Journal of Marriage and Family, 60: 734-744.

Society of Human Resource Management. 2016. 2016 employee benefits: Looking back at 20 years of employee benefits offerings in the U.S. Available at https://www.shrm.org/ hr-today/trends-and-forecasting/research-and-surveys/ pages/2016-employee-benefits.aspx.

Song, Z., Foo, M., \& Uy, M. A. 2008. Mood spillover and crossover among dual-earner couples: A cell phone event sampling study. Journal of Applied Psychology, 93: 443-452.

Starbuck, W. H., \& Milliken, F. J. 1988. Executives' perceptual filters: What they notice and how they make sense. In D. Hambrick (Ed.), The executive effect: Concepts and methods for studying top managers: 35-65. Greenwich, CT: JAI Press.

Stigliani, I., \& Ravasi, D. 2012. Organizing thoughts and connecting brains: Material practices and the transition from individual to group-level prospective sensemaking. Academy of Management Journal, 55: 1232-1259.

Strauss, A. 1978. Negotiations: Varieties, contexts, processes and social order. San Francisco: Jossey-Bass.

Strauss, K., Griffin, M. A., \& Parker, S. K. 2012. Future work selves: How salient hoped-for identities motivate proactive career behaviors. Journal of Applied Psychology, 97: 580-598.

Stryker, S. 1968. Identity salience and role performance: The importance of symbolic interaction theory for family research. Journal of Marriage and Family, 30: 558-564.

Stryker, S. 1980. Symbolic interactionism: A social structural version. Palo Alto, CA: Benjamin/Cummings.

Stryker, S., \& Burke, P. J. 2000. The past, present, and future of an identity theory. Social Psychology Quarterly, 63: 284-297.

Swann, W. B., Jr., Rentfrow, P. J., \& Guinn, J. S. 2003. Selfverification: The search for coherence. In M. R. Leary \& J. P. Tangney (Eds.), Handbook of self and identity: 367-383. New York: Guilford Press.

Taber, B. J., \& Blankemeyer, M. 2015. Future work self and career adaptability in the prediction of proactive career behaviors. Journal of Vocational Behavior, 86: 20-27.

Taylor, J. R., \& Van Every, E. J. 2000. The emergent organization: Communication as its site and surface. Mahwah, NJ: Lawrence Erlbaum Associates.

Thoits, P. A. 1983. Multiple identities and psychological well-being: A reformulation and test of the social isolation hypothesis. American Sociological Review, 48: 174-187.

Thoits, P. A. 1992. Identity structures and psychological wellbeing: Gender and marital status comparisons. Social Psychology Quarterly, 55: 236-256.

Tichenor, V. 2005. Maintaining men's dominance: Negotiating identity and power when she earns more. Sex Roles, 53: 191-205.

Trice, H. M. 1993. Occupational subcultures in the workplace. Ithaca, NY: ILR Press.

Ugwu, L. 2009. Dual-career couples: Coping with multiple role stress. Gender \& Behaviour, 7: 2229-2244.

Valcour, M. 2015. Navigating tradeoffs in a dual-career marriage. Harvard Business Review, April 14: https:/hbr.org/ 2015/04/navigating-tradeoffs-in-a-dual-career-marriage.

Van Willigen, M., \& Drentea, P. 2001. Benefits of equitable relationships: The impact of sense of fairness, household division of labor, and decision making power on perceived social support. Sex Roles, 44: 571-597.

Vignoles, V. L., Regalia, C., Manzi, C., Colledge, J., \& Scabini, E. 2006. Beyond self-esteem: Influence of multiple motives on identity construction. Journal of Personality and Social Psychology, 90: 308-333.

Voydanoff, P. 1988. Work and family: A review and expanded conceptualization. Journal of Social Behavior and Personality, 3(4): 1-22.

Wayne, J. H., Casper, W. J., Matthews, R. A., \& Allen, T. D. 2013. Family-supportive organization perceptions and organizational commitment: The mediating role of work-family conflict and enrichment and partner attitudes. Journal of Applied Psychology, 98: 606-622.

Weick, K. E. 1995. Sensemaking in organizations. Thousand Oaks, CA: Sage.

Weick, K. E., \& Roberts, K. H. 1993. Collective mind in organizations: Heedful interrelating on flight decks. Administrative Science Quarterly, 38: 357-381.

Weick, K. E., Sutcliffe, K. M., \& Obstfeld, D. 2005. Organizing and the process of sensemaking. Organization Science, 16: 409-421.

Weiss, H. M., \& Cropanzano, R. 1996. Affective events theory: A theoretical discussion of the structure, causes and consequences of affective experiences at work. Research in Organizational Behavior, 18: 1-74.

Westman, M. 2001. Stress and strain crossover. Human Relations, 54: 717-751.

Withey, M., Daft, R. L., \& Cooper, W. H. 1983. Measures of Perrow's work unit technology: An empirical assessment and a new scale. Academy of Management Journal, 26: 45-63.

Wood, J. T. 1986. Different voices in relationship crises: An extension of Gilligan's theory. American Behavioral Scientist, 29: 273-301.

Zellmer-Bruhn, M. E. 2003. Interruptive events and team knowledge acquisition. Management Science, 49: 514-528.

Zhang, Y., Liao, J., Yan, Y., \& Guo, Y. 2014. Newcomers' future work selves, perceived supervisor support, and proactive socialization in Chinese organizations. Social Behavior and Personality, 42: 1457-1472. 
Wayne S. Crawford (wayne.crawford@uta.edu) is an assistant professor at University of Texas at Arlington. He received his Ph.D. from the University of Alabama. His research focuses on employees' work and life domains, identity, and supervisor-subordinate dynamics in the workplace, including leadership and abusive supervision.

Merideth J. Thompson (merideth.thompson@usu.edu) is an associate professor at Utah State University. She earned her Ph.D. at Vanderbilt University. Her research focuses on how employees' work and nonwork lives affect one another and on toxic workplace behaviors like abusive supervision and incivility.

Blake E. Ashforth (blake.ashforth@asu.edu) is the Horace Steele Arizona Heritage Chair at Arizona State University. He received his Ph.D. from the University of Toronto. His research concerns the ongoing dance between individuals and organizations, including identity and identification, socialization and newcomer adjustment, and the links among individual-, group-, and organization-level phenomena. 
Copyright of Academy of Management Review is the property of Academy of Management and its content may not be copied or emailed to multiple sites or posted to a listserv without the copyright holder's express written permission. However, users may print, download, or email articles for individual use. 